\title{
Recruitment Model Of Political Party For A Political Position In North Sumatera Province, Indonesia
}

\author{
Walid Musthafa Sembiring, Heri Kusmanto, Zafar Siddik Pohan \\ Faculty of Social and Political Sciences, University of Sumatera Utara, Indonesia \\ muryantoamin@usu.ac.id
}

\begin{abstract}
The recruitment of political party for a political position in local level in Indonesia mostly done in a transactional way through party elites in the local level. The management of party does not apply the democratic principle on the party recruitment and regeneration at the local level so that the chosen officer or government often exposed by legal issue and an in effectivegovernment. This study aims to analyze the recruitment model of a politicalparty in North Sumatera for the political position (governor and mayor).

By using qualitative research method through Focus Group Discussion (FGD) and in-depth interview with political party elites, academics, elements of government and political party observer society in North Sumatera. Research results how sthatthe recruitment conducted by the political party to become a political officer is transactional. Most of them do not have complete documents of the recruitment process at the local level. Some of the parties which owning complete documents, inconsistently conduct the recruitment process as mentioned in documents. The recruitment of political party in local level also push as ide the potential cadres because of political fundmatter.
\end{abstract}

Keywords: political recruitment, political party, recruitment model, political transaction, local politics

\section{INTRODUCTION}

Democratization after the Reformation has changed the face of politics in Indonesia, both at national and local level (Choi, 2011). The transformation of post-New Order political parties seeks to exclude undemocratic practices, although some still leave the military and elite elements of the New Order oligarchy (Fukuoka, 2013). Furthermore, the dynamics of model relations and the form of political party activities with democratic principles are increasingly a concern in Indonesia. The analysis between the normative function of political parties and those carried out empirically is one of the more widespread studies today (Bader, 2014). The study of political parties in a democratic state is well founded, because political parties are the main channel that liaises between communities through their representatives in parliament with the state, and acts to control the course of power (Dahl, 1971). Political parties are the main key in implementing democratic consolidation so that the principle of representation can be done (Kalua, 2011). While there is broad agreement that political parties play an important role in the consolidation of democracy, there is little agreement on what particular qualities the parties should have (Randall \&Svåsand, 2002).

Consolidation of democracy in Indonesia after the New Order became the main political agenda of reform. One of the main conditions of the realization of democratic consolidation is the holding of free and fair elections (WoleOlaleye, 2004). Further democratic consolidation also involves changes in attitudes and institutions that normalize political democracy and minimize political uncertainty, both at national and local levels (Linz \&Stepan, 1996). Democracy is a system that requires the existence of an intermediary institution that becomes the liaison state with the community. Up to the present time, political parties considered by most political researchers are the intermediary institutions. Although it is well known that it is often not a political party that undermines the old regime, but returns to a political party one must observe the essence of consolidating democracy. Consolidation requires political parties to build a new competition system for political contestation. The Party is a modern institution that focuses on organizing the structure and incorporation of individual interests (O'Donnell \&Schmitter, 1986).

Historical fact that after Soeharto's New Order regime in 1998, political parties in Indonesia experienced a very rapid development in terms of numbers. Hundreds of political parties were formed at this time, but in the process of verification of political parties participating in the election, there were only 48 political parties eligible to become election participants in 1999, 
the first election in the early reforms. The 1999 elections did not work out perfectly, but as a milestone in the resumption of democracy in Indonesia with the participation of many political parties. In the early days, most political parties participating in the general elections in 1999, especially the new parties, were still unable to compete by prioritizing the program and ideology of their party, more on the form of mass political parties. Political parties are vying to attract mass support by using euphoria over the collapse of the New Order regime.

At the local level in Indonesia, the current conditions are in line with the increasingly democratic national dynamics. The direct election of regional heads, for example, mirrors efforts to increase democracy at the local level. In this condition, the role of political parties is getting stronger as a guarantor of the implementation of the democratic process openly and accessible to all levels of society. The major challenge for political parties in Indonesia today is the management of recruitment and placement of cadres in political positions and party cadresisations that have not been properly implemented, and also the centralization of all activities and decisions of political parties in the central board.

The events of major political changes in the early days and until the end of the New Order, it is difficult to find the role of political parties in encouraging change, compared with the role of other community groups such as students. It is more appropriate to say that political parties are those who enjoy political change driven by other social forces. When we look closely at this, there are two more widespread trends in our political practice and also in the behavior of political parties Indonesia.

\section{RESEARCH METHOD}

This research uses qualitative approach with case study as research strategy. The choice of qualitative approach is done with the aim to describe and analyze the social phenomenon that is happening (Yin, 2009). Therefore, this type of research uses an explanatory case study strategy. The flexibility and access possessed in the event under study still exists. For example, researchers can contact the investigated abuser to conduct an interview. In contrast to historical type studies pertaining to the past, that is, when no more live witnesses can be reached. Case studies are used to track current events, which are related to local politics in Indonesia in the context of party political recruitment at the local level in political offices.

\section{LITERATURE EREVIEW}

A.Political and Democratic Party

With regard to political parties and party systems, Andreas Uffen concluded that political parties in Southeast Asian countries, including Indonesia, are very weak in party politics, this is due to party party behavior and activities carried out by political parties (Ufen, 2008).

Political parties have a very important position (status) and role (role) in every democratic system. The Party plays a very strategic liaison role between government processes and citizens. In fact, many argue that political parties that actually determine democracy," political parties created democracy". Political parties are very important pillars to strengthen the degree of institutionalization (the degree of institutionalization) in any democratic political system "modern democracy is unthinkable save in terms of the parties" (Schattschneider, 1942).

However, there are also many critical and even skeptical views of political parties, among which state that the political party is actually nothing more than a political vehicle for a group of ruling elites or intends to satisfy its own 'lust of power'. Political parties serve only as a tool for the lucky few who succeed in winning the voice of the gullible people, to enforce certain public policies 'at the expense of the general will' orpublicinterest(Rousseau, 1999).

Political parties are in any way very instrumental in the dynamic process of values and interests of the constituents it represents to determine policy in the context of state activities. Political parties that act as intermediaries in state decision-making processes, connecting citizens with state institutions. According to Robert Michels in his book,"Political Parties, A Sociological Study of the Oligarchical Tendencies of Modern Democracy", "...organizations are the only means of economy or politics to form collective will" (Michels, 1962). 
The process of institutionalizing democracy is ultimately largely determined by the institutionalization of political party organizations as an integral part of the democratic system itself as Yves explained, "A democratic system without political parties or with a single party is impossible or at any rate hard to imagine" (Mený \& Surel, 2002). A political system with only one political party is hard to imagine to be called democratic, especially if it is without a political party at all.

The level or degree of institutionalization of political parties themselves in the democratic system, according to Yves Meny, depends on 3 (three) parameters, namely (i) "its age", (ii) "the depersonalization of organization", and (iii) "organizational differentiation" (Mený \& Surel, 2002)Every normal organization grows and develops naturally according to its own timeline. The older age, the ideas and values adopted within the organization are increasingly institutionalized into a tradition within the organization.

In general, ordinary political scientists describe the existence of 4 (four) functions of political parties. The four functions of the political party according to Miriam Budiardjo include the following: (i) the means of political communication, (ii) political socialization, (iii) political recruitment, and (iv)conflict management (Budiardjo, 2000). The functions of political parties include the functions of (i) mobilization and integration, (ii) means of establishing influence on voting patterns; (iii) means of political recruitment; and (iv) means of elaboration of policy options(Mený \& Surel, 2002).

Referring to Paige Johnson Tan's research, arguing that political parties in Indonesia are significantly an important part of the consolidated democratic system, yet at the same time political parties are still weak institutionally. The party rests more on the charism of the leader, not on the modern organizational structuring system. This also implies the frequent occurrence of disunity in political parties that resulted in the emergence of political frustration of cadres and society and the process of democratic consolidation itself(Johnson Tan, 2012). However, it must be realized that every 'representative democracy' system, commonly understood that sovereign people's participation is mainly channeled through popular vote to establish representative institutions. This representative mechanism is considered by itself to be effective for the purpose of ensuring the representation of the aspirations or the interests of the people. Therefore, in the representative system, the position and role of political parties are considered very dominant(Oliver, Prosser, \& Rawlings, 2011).

\section{RESULT AND DISCUSSION}

As the strategic role of political parties has been put forward, we gain an information on the existence of political parties as a political instrument within the framework of democracy and million as a way to gain power. The problem then arises when the individuals within the political party are oriented only on how to gain that power, so that power becomes the final estuary of political contestation pursued by political parties. So the substantive goal of political activity that emphasizes the functional aspect of politics becomes neglected, namely to maintain or regulate the various kinds of public affairs.

The activity of political parties only stops at the level of how to gain power, when it should not be so, but must be complemented by how the power which has been obtained is used for the greatest prosperity of the people. On the other hand there is an alienation of political parties to the community, resulting in the distance and the gap between political parties and the community. This great distance makes people start thinking that they can live without a political party. The saddest thing is the deep disappointment in society because they feel they have never been noticed and dealt with by political parties. This will clearly reduce the apolitical population rate, and reflected in the low political participation of the community in every election.

In addition to the only factor that emphasizes the orientation of power and the occurrence of alienation of political parties to society, the problem faced by political parties is "corruption". Since 1999, the "tradition of corruption" ahead of the elections is a matter of course. In 1999, a corruption case Liquidity Support of Bank Indonesia (Bantuan Likuiditas Bank Indonesia) rose to the surface, followed by the 2004 election 
with a bribery case of Gubernatorial Election BankofIndonesia Miranda Gultom to the members The House of Representatives of the Republic of Indonesia for the winner. In 2009, the Century Bank case shook the public with all its plays. In the 2014 election, corruption cases involving the Treasurer of the Democratic Party Nazaruddin flowing into political funding and allegedly for the preparation of the 2014 Election. Budget AgencyThe House of Representativesalso attached to corruption cases for the interests of political parties. Disbursement of Funds for the Acceleration of Regional Infrastructure Development also allegedly full of corruption that ended in funding of political parties, the case of Wisma Athletes, and also Hambalang. And there

Table 1.

FractionsandChairsforRegional RepresentativesCouncilofNorth Sumatera

Period 2014-2019

\begin{tabular}{|l|l|l|l|}
\hline NO & \multicolumn{1}{|c|}{ NAME OF FRACTIONS } & \multicolumn{1}{|c|}{ CHAIRMAN } & CHAIRS AMOUT \\
\hline 1 & PartaiGolkar & IndraAlamsyah, S.H. & 17 \\
\hline 2 & PDI Perjuangan & Budiman P Nadapdap, S.E. & 16 \\
\hline 3 & PartaiDemokrat & H. Saleh Bangun & 14 \\
\hline 4 & PartaiGerindra & Ir. YantoniPurba, M.M. & 13 \\
\hline 5 & PartaiHanura & AduhotSimamora & 10 \\
\hline 6 & PartaiKeadilan Sejahtera & Zulfikar & 9 \\
\hline 7 & PartaiAmanat Nasional & H. SyahAfandin, S.H. & 6 \\
\hline 8 & PartaiNasDem & Drs. Anhar A. Monel, M.A.P. & 5 \\
\hline 9 & PersatuanKeadilanBangsa & RobiAgusmanHarahap, S.H. & 10 \\
\hline & \multicolumn{2}{|r|}{ Total } & $\mathbf{1 0 0}$ \\
\hline
\end{tabular}

Source: Secretariat of theRegional RepresentativesCouncilofNorth Sumatera

In the context of political recruitment for the legislature, there are some issues in political parties that have the potential to disrupt the development of democracy, especially at the local level of North Sumatra. First, the proportional electoral system has perpetuated the dominance of the oligarchy in the recruitment process. The party elite in the area is very powerful to the recruitment process, which determines who will occupy the "hat number" and who miserably occupies the "shoe number". However, the elite oligarchy is undemocratic, but tends to preserve practicesCorruption of Collusion and Nepotismwhichisveryclosed. The pattern does not produce a representative and mandatory parliament, but rather a partisan parliament that is more loyal to the political party. Although the electoral system is no longer based on the serial number, but on the majority of votes and / or who get the Voter Distribution Number (VDN) , but the are many other corruption cases that are allegedly related to political parties.

Political parties that have seats inthe Regional Representatives Council Province of North Sumatera there are as many as eleven political parties that are converted into Nine Factions at Regional Representatives Council Province of North Sumatera. The party that merges into one Faction is Partai Persatuan Pembangunan (PPP), Partai Keadilan dan Persatuan Indonesia (PKPI) and Partai Kebangkitan Bangsa (PKB). Number of seats at there as many as 100 seats and spread in 11 political parties. position of the serial number strongly determines the choice of society and also the calculation when no one gets the valueof VDN.

Secondly, in the recruitment process there is no good linkage between political parties and civil society. Civil society is viewed only numerically as a number, not as a constituent that must be respected and championed. Community organizations are only placed as underbow, a political machine that mobilizes the masses, not as the basis of the party's political struggle. On the contrary, the activists of civil society organizations do not view political parties as part of the social movement to influence policy and control the state, but only as "political vehicles" to gain power and power.As a result, MPs are oriented only on power and wealth. Not a few membersHouse ofRepresetativeswhich ignore forums or extra parliamentary participation, as they claim 
thatHouse ofRepresetativesbecome the most legitimate representative institution and the participation is not regulated in local laws or regulations.

Third, in the process of recruitment of political parties often apply the approach "asalcomot" (takingrandomly)against a candidate viewed as a "political machine". This approach tends to ignore the aspect of legitimacy, commitment, capacity, and mission of struggle. The former soldiers and officials are taken not because they have visionmissions, but because they have remnants of power networks. Employers are recruited for having a lot of money that can be used effectively for mobilization funds to money politics. Celebrities are taken because they have many fans. The scholars were also recruited for having traditional followers. Political parties easily take on social, intellectual, or academic figures on campus who pursue power and want to make the party a way for vertical mobility.

In the limited focused discussions conducted, the fact that almost all political parties are performing character recruitment programs. The recruitment of the figures is intended for the party not to lose voters. Political parties in North Sumatra partly recruit public figures openly and there are some political parties that do so in private.

Recruitment of the figures is done by open and closed model, the Hanura Party of North Sumatra, for example, make an announcement for the recruitment of open figures, while PDIP recruits the characters with closed.

The process of political party recruitment in North Sumatra is indeed impressed to be done only as part of the process of performing the functions of the party alone. The size used is more focused on the person's personality and also the financial ability.
Fourth, the electoral process and the recruitment process work in the context of a "less-educated and critical" floating mass. So far people have not received political education, especially from political parties, resulting in millions of traditional voters who are particularly vulnerable to mobilization practices. Political parties do not play an adequate role in political education to the public. Until now the majority of Indonesian people are silent majority, calm, apathetic (ignorant) and not critical in facing the political process. As a result, participative political culture (civic culture) has not been established. Conditions like this certainly do not allow for an open and participatory recruitment process.

Recruitment of cadres conducted by political parties in North Sumatra is currently also done by taking cadres coming from the wing of the party organization, both youth, women and other party wings. This is done with the consideration of the efficiency of the party's work in recruiting cadres, as well as associated with minimal party funding issued if recruiting cadres through the existing party wing.

In general, the political recruitment system in almost all political parties in North Sumatra, both for legislative and executive, has not gone well. Political parties do not yet have clear and rigid recruitment manuals governing how recruitment takes place. In some political parties, such as Golkar, PDIP which has a recruitment and regeneration module, the implementation stage is not consistently executed and strong commitment. This is of course very detrimental to the development of democracy at the local level, even at the national level. The model of recruitment of political parties in North Sumatra can be seen in the following table. 
Tablel 2.

Recruitment Model of Political Party in North Sumatera

\begin{tabular}{|c|l|l|l|}
\hline No & TypeofRecruitment & \multicolumn{1}{|c|}{ Recruitment Model } & \multicolumn{1}{|c|}{ Explanation } \\
\hline 1 & DistrictHead & $\begin{array}{l}\text { a. Transactional } \\
\text { b. Figures and sturdiness } \\
\text { c. Can be filled by non-cadres } \\
\text { d. Final decision in the Central } \\
\text { Board } \\
\text { e. Semi-open }\end{array}$ & $\begin{array}{l}\text { The recruitment } \\
\text { process tends to } \\
\text { be closed and } \\
\text { transactional }\end{array}$ \\
\hline 2 & LegislativeMembers & $\begin{array}{l}\text { a. Party elites at the local level } \\
\text { b. Transactional } \\
\text { c. System not open / clear } \\
\text { d. Do not consider community input }\end{array}$ & $\begin{array}{l}\text { In the legislature, } \\
\text { there are frequent } \\
\text { conflicts between } \\
\text { internal party } \\
\text { administrators in } \\
\text { the serial number } \\
\text { and election area }\end{array}$ \\
\hline 3 & Cadre & $\begin{array}{l}\text { a. Wing and party underbow } \\
\text { organization } \\
\text { b. Certain segmentation (youth, } \\
\text { women, etc.) } \\
\text { c. Figure }\end{array}$ & $\begin{array}{l}\text { hot all parties } \\
\text { recruitment } \\
\text { manuals, and if } \\
\text { they exist, they are } \\
\text { not consistently } \\
\text { implemented and } \\
\text { with strong } \\
\text { commitments }\end{array}$ \\
\hline
\end{tabular}

Processed from the results of research

\section{CONCLUSION}

Based on the results of the research that has been described, the problems that occur in political parties, especially in North Sumatra caused by the weakness of the system of regeneration and political party political recruitment. The majority of political parties do not have structured and systematic documents of the morals. In addition, the electoral system in both the legislative and the elections has exacerbated the birth of the regeneration system and the recruitment of political parties.

The pattern of recruitment in the body of political parties must be improved by modeling some models of management of political parties in developed countries. Furthermore, it should be avoided the birth of karbitan cadres who join the political party only because of the popularity factor and the funds they have so with the capital it is believed they will win and can support the party. Therefore, political parties must reorganize themselves, complemented by a complete overhaul of the political system and party system in Indonesia, as well as a powerful set of rules to monitor and open the funding of political parties in order to avoid infidelity between politicians and businessmen as a result of the political contracts they havebuilt.

\section{REFERENCES}

Bader, V. (2014). Crisis of political parties and representative democracies: rethinking parties in associational, experimentalist governance. Critical Review of International Social and Political Philosophy, 17(3), 350376.

https://doi.org/10.1080/13698230.2014.886 380

Choi, N. (2011). Local politics in Indonesia: pathways to power. Routledge contemporary Southeast Asia series. https://doi.org/10.1080/00472336.2012.721 664 
Dahl, R. A. (1971). Dahl- Polyarchy. In Polyarchy: Participation and Opposition (pp. 1-16).

Fukuoka, Y. (2013). Democratization Indonesia ' s “ democratic transition " revisited : a clientelist model of political transition. Democratization, 20(April 2015), 37-41. https://doi.org/10.1080/13510347.2012.669 894

Johnson Tan, P. (2012). Reining in the Reign of the Parties: Political Parties in Contemporary Indonesia. Asian Journal of Political Science, 20(2), 154-179. https://doi.org/10.1080/02185377.2012.714 132

Kalua, P. (2011). Forum for Development Studies The Extent of Political Party Institutionalization in Malawi: The Case of United Democratic Front ( UDF ) and Malawi Congress Party ( MCP ) The Extent of Political Party Institutionalization in Malawi: The. Forum for Development Studies, 38(February 2015), 37-41. https://doi.org/10.1080/08039410.2010.548 078

Linz, J. J., \& Stepan, A. C. (1996). Modern nondemocratic regimes. Juan J. Linz \& Alfred Stepan, Problems of Democratic Transitions and Consolidation, 42.

Mený, Y., \& Surel, Y. (2002). The Constitutive Ambiguity of Populism. In Democracies and the Populist Challenge (pp. 1-21). https://doi.org/10.1057/9781403920072

Michels, R. (1962). Oligarchy. In The Sociology of Organizations: Basic Studies.

O'Donnell, G., \& Schmitter, P. C. (1986). Transitions from Authoritarian Rule: Tentative Conclusions about Uncertain Democracies. America, $62(2), \quad 81$. https://doi.org/10.1166/sam.2011.1150

Oliver, D., Prosser, T., \& Rawlings, R. (2011). The Regulatory State: Constitutional Implications. The Regulatory State: Constitutional Implications.

https://doi.org/10.1093/acprof:oso/978019 9593170.001 .0001

Randall, V., \& Svåsand, L. (2002). Party Institutionalization in New Democracies. Party Politics, 8(1), 5-29. https://doi.org/10.1177/135406880200800 1001

Rousseau, J.-J. (1999). The Social Contract. Theology (Vol. III). Retrieved from
http://www.amazon.com/Social-ContractJean-Jacques-Rousseau/dp/145380689X

Schattschneider, E. (1942). Party Government. American government in action series. https://doi.org/10.2307/1949637

Ufen, A. (2008). Political party and party system institutionalization in Southeast Asia: lessons for democratic consolidation in Indonesia, the Philippines and Thailand. The Pacific Review, 21(3), 327-350. https://doi.org/10.1080/095127408021341 74

Yin, R. K. (2009). Case Study Research: Design and Methods. Essential guide to qualitative methods in organizational research (Vol. 5). https://doi.org/10.1097/FCH.0b013e31822d da9e 
